Article

\title{
Determining the Presence of Spalted Wood in Spanish Marquetry Woodworks of the 1500s through the 1800s
}

\author{
Patricia T. Vega Gutierrez * and Seri C. Robinson \\ Department of Wood Science \& Engineering, Oregon State University, Corvallis, OR 97331, USA; \\ seri.robinson@oregonstate.edu \\ * Correspondence: patricia.vega@oregonstate.edu; Tel.: +1-541-286-8259 \\ Academic Editor: Marco Malagodi \\ Received: 16 September 2017; Accepted: 2 November 2017; Published: 4 November 2017
}

\begin{abstract}
The process of using fungal-colored wood (spalted wood) for marquetry and intarsia woodworks in Italy and Germany was very popular from the 1400-1600s, with some instances continuing as late as the 1800s. While spalted marquetry in these countries is relatively well documented, less is known about its use in other parts of Europe. One of the primary reasons for this lack of knowledge is the difficulty in identifying spalted wood, especially the blue-green variety produced from Chlorociboria species, from wood dyed with copper-based compounds or other synthetics. The most reliable testing method involves destructive sampling, where a small piece is taken from the work, the pigment extracted, and an analysis performed. Such sampling is simply not feasible, nor often allowed, on ancient artwork. To make a reliable, non-destructive identification of spalted wood, a visual method based on anatomical characteristics of spalted wood was developed to differentiate spalted wood from dyed wood. High-resolution pictures were taken from wooden artifacts containing blue-green colored wood in collections at the National Museum of Decorative Arts (MNAD), the Royal Site Monastery El Escorial and the Bilbao Museum of Fine Arts in Spain. The concentration of pigment in the rays, the color distribution, the size of the piece and the date of production, were analyzed. With the use of this new visual method, it was possible to determine that intarsia artifacts, held in Spain but of Augsburg origin from the 1500-1600s, contained spalted wood details. Meanwhile, Spanish and Italian intarsia artifacts from the 1800 s were found to only contain dyed wood.
\end{abstract}

Keywords: spalted wood; Chlorociboria; intarsia; marquetry; xylindein

\section{Introduction}

Intarsia and marquetry are ancient wood art forms that evolved from inlay techniques using ceramics and metals. Generally, they involved very small pieces of wood (veneer, for marquetry, and larger pieces for intarsia), often colored, and were glued together onto a framework to make a larger image.

Wood intarsia, and later, marquetry, was very popular in Europe between the 1400s through the 1600s, although the general techniques were around much earlier and persisted well into the 1800s [1]. Of particular interest in these works was the use of non-wood items, such as tortoiseshell and mother of pearl, and also naturally colored pieces of wood (wood that was not dyed, but rather, found in a colored state). This wood, now known worldwide as "spalted" wood, was a highly sought after commodity item for woodworking guilds. The blue-green type of spalted wood, especially, was coveted, as it did not oxidize and remained stable in light. Other dyes within the blue/green 
spectrum were more affordable, and manufactured especially in the 1700s and beyond, but did not convey the same colorfastness [1].

Spalting is the result of fungal metabolic processes that create unique, colored patterns inside of wood [2]. These patterns are created by three classes of fungi that may occur individually or simultaneously in wood: bleaching, zone lines, and pigmentation. Bleaching is the result of the chemical modification of the cell wall, and mostly occurs when basidiomycete fungi degrade lignin. The second type, zone lines, are formed from the extracellular production of melanin (and occasionally other pigments) from ascomycetes and/or basidiomycetes [3]. Finally, pigmentation occurs when fungi secrete extracellular pigments broadly throughout wood (instead of in a line, as with zone lines) [4], see Figure 1.

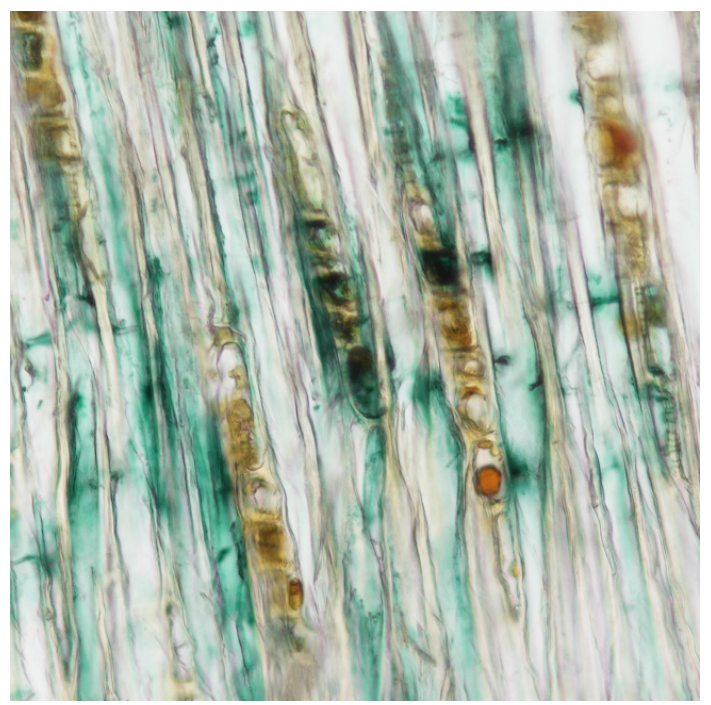

(a)

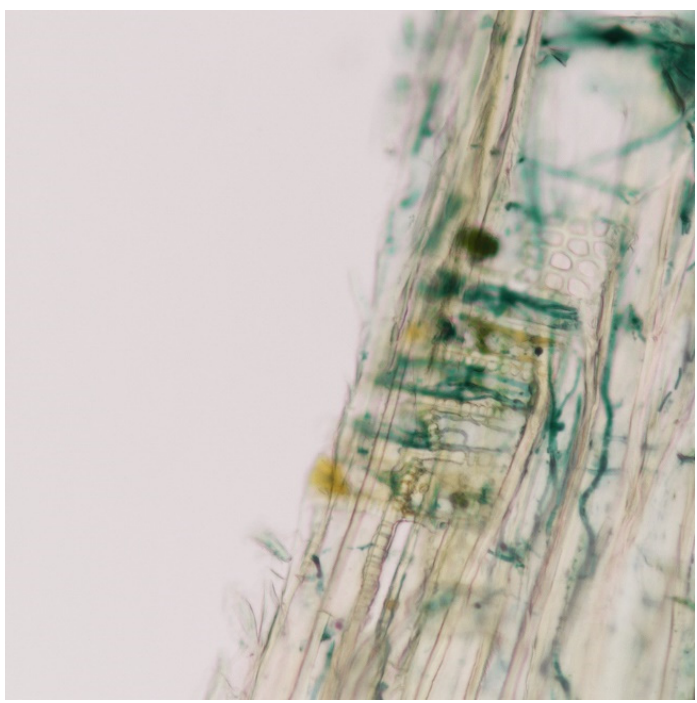

(b)

Figure 1. Microscopic images of a veneer of spalted poplar (Populus nigra) used in a tall case clock in the mid 1700s. (a) Tangential plane of veneer poplar showing mycelium expanding in ray cells (arrows), (b) Radial plane shows higher concentration of xylindein in rays than in fibers and vessels (arrows). Photo by Sarath M. Vega Gutierrez.

Pigmentation, especially the kind utilized for spalted wood, is mostly caused by ascomycetes belonging to the Helotiales order. Four species from this order are of special importance to spalting: Chlorociboria aeruginascens (Nyl.) Kanouse, Chlorociboria aeruginosa (Oeder) Seaver, Scytalidium cuboideum (Sacc. and Ellis) Sigler and Kang, and Scytalidium ganodermophthorum Kang, Sigler, Lee and Yun [5-15]. Of these four species, the Chlorociboria species and the blue-green pigment they produce, known as xylindein, have the most historical significance in terms of historical woodwork.

Wood stained blue-green by Chlorociboria species can be found in woodworks in Europe as far back as the 1200s $[1,16,17]$, and became especially popular between the 1400s and 1600s $[16,18,19]$. The popularity of this art form began to peak when the intarsia technique migrated from Italy and evolved into gesägte intarsia (sawn intarsia) in Augsburg and Nuremberg at the beginning of the 16th century [20]. Due to the rise in exposure and popularity, the colored wood became a commodity of free trade around Augsburg [21], where the highest quality marquetries were made [22]. Spalted wood marquetries remained a closely guarded guild technique within this region $[1,21]$. As such, a great deal is known about spalted marquetries across Germany and Italy (where they originated), but little is known about how the art form may have spread to other regions of Europe, and if it did spread, how it was utilized. 
The ascension of Charles V to the Spanish throne in 1516 started the ruling of the Habsburg family in both Spain and Germany. The Germanic origin of the Habsburgs in Spain lead to an intense commercial exchange between Spain and Germany that gave access to fine intarsia pieces made by the masters of southern Germany (Nuremberg and Augsburg). Interest in owning intarsia, especially pieces utilizing blue-green wood, continued to spread throughout Europe and was eventually adopted by most of the Holy Roman Empire aristocracy [20]. In tandem, important trading companies localized in southern Germany intensified commerce and cultural exchange.

During the reign of Charles V from 1500 to 1558, and his son Phillip II from 1556 to 1598, German artists and crafters established themselves in Spain and/or would export their pieces to Spain [22]. It is unknown whether the technique of utilizing spalted wood also moved into Spain, or if it remained a guild secret of German masters.

A relatively easy way to determine if the practice moved into Spain would be to look at museum pieces from the region made by native woodworkers, as well as those that were imported, to see which contain spalted wood (especially the blue-green variety). Unfortunately, due to the age of the works and secrecies of the wood guilds that produced them, works from this period, in any museum, are not necessarily labeled as containing spalted wood. This creates a hurdle for researchers looking to trace the history of spalted woods and understand ancient guild practices, as it can be notoriously difficult to identify blue-green spalted wood from wood stained with copper acetate (verdigris) and copper sulfate (vitriol) - pigments used to obtain a blue-green color during the same period [18]. Current methods for identification of xylindein in ancient wood artworks can be done either through destructive sampling using an HPLC [18] that involves removal of wood material but is highly reliable, and VIS spectroscopy, a method not as accurate as HPLC, but is also not destructive to the wood [19].

As most museums and collectors have a great deal of stored wood artwork with unknown composition, but are unwilling to have pieces of their works removed, however small, to facilitate HPLC analysis, a more reliable, nondestructive test is needed to determine xylindein presence in ancient marquetries. Herein, the authors discuss a simple, visual method of separating spalted wood from dyed wood, specific to Chlorociboria species, which can aid museums in identification of spalted wood components. The ability to quickly and reliably tell Chlorociboria-stained wood from dyed wood will allow curators more flexibility in tracing works from famous guild families (such as the Weisshaupt family), help determine how the practice of utilizing spalted wood moved throughout Europe, help further elucidate the lives and practices of these notoriously secretive woodworking guilds from European history, and at its most basic, help identify spalted wood in otherwise dyed marquetries, and shed light on an ancient art practice that has been mostly forgotten by time.

\section{Materials and Methods}

\subsection{Location of Potential Spalted Wood Pieces}

Potential artworks containing Chlorociboria wood were identified in the Digital Network of Museum Collections from Spain (Red Digital de Colecciones de Museos de España) also called CER.ES. This network holds an online catalog with more than 400,000 images and technical information from collections from 95 museums. The search terms "wood" and "marquetry" were used.

The CER.ES database then provided the inventory code number, the type of object, its location, the materials used in their making, the techniques used, the dimensions, a description of the piece, the cultural context, the date of making, place of production, who made it, history of the object and bibliography that mentions or supports the description of the object and pictures of the pieces from different angles and detail [23]. This information may or may not include the wood species used in the piece, and often do not contain the species of the dyed wood, especially the blue-green wood from Chlorociboria [1].

From these listings, museums were selected based upon those that contained spalted wood artifacts. The National Museum of Decorative Arts was selected as it had wooden furniture pieces with inlaid green wood, as described in the profile, which looked promising for spalting. 
Within the database of the National Museum of Decorative Arts, a bibliographical search was done using keywords (in Spanish) "Spain", "marquetry", "wood", and "green". While no pieces met these search codes, they did pull up the name of a Spanish researcher named María Paz Aguiló Alonso, who is a specialist on Spanish furniture and its history. The decision was made to contact Dr. Aguiló Alonso and work with her personally on identification of spalted pieces.

Dr. Aguiló Alonso identified "German doors" of interest, which contain intarsia panels with blue-green wood (See Figure 2) in five doors at the Royal Monastery San Lorenzo de El Escorial [24]. She also knew of a bureau located at the Bilbao Fine Arts Museum [20] with intarsia and the use of blue-green spalted wood. These were the only locations identified as potentially having spalted, so they were the locations investigated.

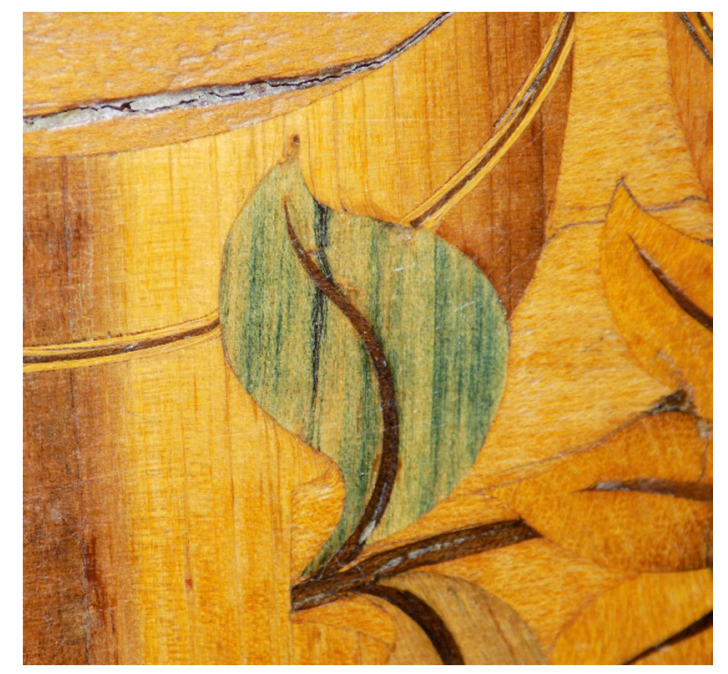

Figure 2. Detail of panel of the Ambassador Room's door at the Royal Monastery San Lorenzo de El Escorial, Spain, 1562-1570. Made by Augsburg intarsiatore Bartholomew Weisshaupt. Image shows a piece of blue-green pigmented wood used to depict a leaf. Spalted wood commonly used to portray vegetation during this time period. Photo: Royal Sites Spain.

\subsection{Museum Information and Access}

The National Museum of Decorative Arts, located in Madrid, belongs to the Ministry of Education, Culture and Sports. The Bilbao Fine Arts Museum belongs to the Bilbao City Council, the Bizkaia Provincial Council and the Basque Government. The Monastery and Royal Site of San Lorenzo de El Escorial is located in San Lorenzo de Escorial, Madrid and it is a Royal Site managed by the National Patrimony office which depends directly from the Presidency of Government.

The museums were contacted prior to visiting, in order to obtain permission to access the collections and photograph the pieces. At the National Museum of Decorative Arts, the Documents Department was contacted. This department processed the permit with the museum's board. Access for photographic records and authorization to sample the pieces of blue-green wood for HPLC analysis was stated in the request. The MNAD granted authorization for photographic records (only an approved photographer from their list of registered photographers). Authorization for blue-green wood sampling was denied, as it involved the alteration of the objects and the destruction of the samples.

Access to the Royal Monastery San Lorenzo de El Escorial was done through the National Patrimony Office. The request included similar information as the one provided to the MNAD. The National Patrimony Office sent the request to the Conservation Department that manages directly the Royal Site El Escorial. Authorization for the photographic record was granted. The researchers were given access to the Royal Site (an important tourist destination) before operation hours, and the 
researchers could access the pieces directly with their own equipment. Authorization to sample the pieces of blue-green wood for HPLC analysis was denied, as it involved direct intervention of the doors.

Access to the Bilbao Museum of Fine Arts was requested via the Museum Director. A similar request to the ones presented to the MNAD and El Escorial was presented. The request was sent to the Head of Collections. Authorization for photographic record was granted. The photographer from the Collections Department was in charge of taking the pictures. Authorization to take samples of blue-green wood was denied because in would cause modification of the pieces. Access was granted when the museum was closed to the public. The department of Conservation and Restoration gave access to all the collections of furniture and to documents and historical records related to these pieces.

\subsection{Data Collection and Analysis}

Data obtained for each piece consisted of date, wood species, technique, original location and background history. Pictures in high resolution were obtained of each piece, with emphasis on inlaid blue-green wood (Table 1). Resolution varied based upon what was available at each museum.

Table 1. Information of pieces located in Spain with photographic information.

\begin{tabular}{|c|c|c|c|c|c|c|}
\hline$\#$ & Code & Object & Date & Origin & Image Resolution & Camera \\
\hline \multicolumn{7}{|c|}{ National Museum of Decorative Arts } \\
\hline \multirow{2}{*}{1} & \multirow{2}{*}{ CE02218 } & \multirow{2}{*}{ Bureau } & \multirow{2}{*}{1600} & \multirow{2}{*}{ South Germany } & \multirow{2}{*}{$254 \mathrm{dpi}$} & Nikon D800 \\
\hline & & & & & & Olympus E-M5 \\
\hline 2 & CE02735 & Bureau & 1600 & South Germany & $254 \mathrm{dpi}$ & Nikon D800 \\
\hline 3 & CE02845 & Bureau & 1601 & South Germany & $254 \mathrm{dpi}$ & Nikon D800 \\
\hline \multirow{2}{*}{4} & \multirow{2}{*}{ CE05638 } & \multirow{2}{*}{ Cabinet } & \multirow{2}{*}{1801} & \multirow{2}{*}{ Spain } & $254 \mathrm{dpi}$ & Nikon D800 \\
\hline & & & & & $150 \mathrm{dpi}$ & Olympus E-M5 \\
\hline 5 & CE05648 & Cabinet & 1801 & Spain & $150 \mathrm{dpi}$ & Nikon D800 \\
\hline 6 & CE05725 & Cabinet & 1776 & Italy/Spain & $150 \mathrm{dpi}$ & Nikon D800 \\
\hline 7 & CE19340 & Game table & 1776 & Spain & $254 \mathrm{dpi}$ & Nikon D800 \\
\hline \multicolumn{7}{|c|}{ Bilbao Fine Arts Museum } \\
\hline 8 & $82 / 1477$ & Bureau & $1560-1570$ & South Germany & $350 \mathrm{dpi}$ & Canon EOS 1100D \\
\hline 9 & $82 / 2472$ & Table & $1560-1570$ & South Germany & $350 \mathrm{dpi}$ & Canon EOS 400D Digital \\
\hline \multicolumn{7}{|c|}{ Royal Monastery San Lorenzo El Escorial } \\
\hline 10 & - & Doors & $1560-1570$ & South Germany & $300 \mathrm{dpi}$ & Nikon Coolpix L340 \\
\hline
\end{tabular}

The presence or absence of spalting was determined visually, with the help of high-resolution photography. A professional wood anatomist assisted in the evaluation of cell types from the photographs (no microscopy was used). As all affected wood was hardwood (deciduous), well sanded, and well preserved, cell types were easy to differentiate with the high resolution photography, which, when using a macro lens, gives an image similar to that as with a $10 \times$ hand lens.

To evaluate the pieces, various visual cues were noted that relate to fungal colonization. The first component was where the pigment was concentrated. As fungi tend to colonize wood first where resources are the easiest to procure, ray cells in wood are often more heavily stained than the surrounding area (due to the distribution of the free sugars). This can mean that presence of the blue-green pigment is often easier to distinguish from dyes when one can view the radial plane of the wood, especially in those woods with visible ray fleck. The next important feature was the distribution of the color. Dyes tend to uptake evenly among similar cells, but fungi do not colonize even the same cells at the same rate. Hence, spalted wood is often mottled in color, even within ray cells or vessels. Third, the size of the piece was important. European Chlorociboria fungi primarily grow only on highly decayed wood. This means that blue-green spalted wood often cannot bear a load and is suitable only for small detail work. Finally, the date of the piece was important. Chlorociboria stained wood 
was originally used because there was no durable synthetic option available that could produce such a color $[1,18]$. As such, any wood that is still blue-green in marquetry produced from 1300 to the 1600 time is almost certainly from Chlorociboria. The checklist of visual components evaluated can be seen in Table 2.

Table 2. Spalted wood identification checklist.

\begin{tabular}{lll}
\hline \multicolumn{1}{c}{ Component } & \multicolumn{1}{c}{ Presence and Form } \\
\hline Blue-green colored inlaid pieces (Blue-green) & $\bigotimes$ Present & $\square$ Not present \\
Pigment in ray cells (Pigm-ray) & $\bigotimes$ Present & $\square$ Not present \\
Pigment highly concentrated in ray cells (Concent.) & $\bigotimes$ Present & $\square$ Not present \\
Overall color distribution (Dist.) & $\square$ Regular & $\square$ Irregular \\
Inlaid piece size (Size) & $\bigotimes<10 \mathrm{~cm}$ & $\square>10 \mathrm{~cm}$ \\
Date (Date) & $\bigotimes<1650$ & $\square>1650$ \\
\hline
\end{tabular}

The information gathered from each piece was put together in a matrix (Table 3). An artwork was determined to contain spalted wood from the fungi Chlorociboria aeruginascens and/or C. aeruginosa if all component boxes were checked for a given piece as follows: blue-green colored wood pieces were present, the pigment was present and highly concentrated in the ray cells, the overall color distribution was irregular, the pieces were smaller than $10 \mathrm{~cm}$ and the piece was dated before 1650 . The final category was due to more stable blue-green wood dyes being developed in the 1700s, and some of the dyed wood from this time period has its color remaining today.

Table 3. Spalted wood identification checklist applied with artifacts found in Spanish museums.

\begin{tabular}{|c|c|c|c|c|c|c|c|c|c|}
\hline$\#$ & Code & Object & Origin & Blue Green & Pigm-Ray & Concent. & Dist. & Size & Date \\
\hline 1 & CE02218 & Bureau & $\begin{array}{c}\text { South } \\
\text { Germany }\end{array}$ & Present & Present & Present & Irregular & $<10 \mathrm{~cm}$ & $<1650$ \\
\hline 2 & CE02735 & Bureau & $\begin{array}{c}\text { South } \\
\text { Germany }\end{array}$ & Present & Present & Present & Irregular & $<10 \mathrm{~cm}$ & $<1650$ \\
\hline 3 & CE02845 & Bureau & $\begin{array}{c}\text { South } \\
\text { Germany }\end{array}$ & Present & Present & Present & Irregular & $<10 \mathrm{~cm}$ & $<1650$ \\
\hline 4 & CE05638 & Cabinet & Spain & Present & Present & Present & Irregular & $<10 \mathrm{~cm}$ & $<1650$ \\
\hline 5 & CE05648 & Cabinet & Spain & Present & Not present & Not present & Regular & $>10 \mathrm{~cm}$ & $>1650$ \\
\hline 6 & CE05725 & Cabinet & Italy/Spain & Present & Not present & Not present & Regular & $>10 \mathrm{~cm}$ & $>1650$ \\
\hline 7 & CE19340 & Game table & Spain & Present & Not present & Not present & Regular & $>10 \mathrm{~cm}$ & $>1650$ \\
\hline 8 & $82 / 1477$ & Bureau & $\begin{array}{l}\text { South } \\
\text { Germany }\end{array}$ & Present & Present & Present & Irregular & $<10 \mathrm{~cm}$ & $<1650$ \\
\hline 9 & $82 / 2472$ & Table & $\begin{array}{c}\text { South } \\
\text { Germany }\end{array}$ & Present & Present & Present & Irregular & $<10 \mathrm{~cm}$ & $<1650$ \\
\hline 10 & NA & Doors & $\begin{array}{l}\text { South } \\
\text { Germany }\end{array}$ & Present & Present & Present & Irregular & $<10 \mathrm{~cm}$ & $<1650$ \\
\hline
\end{tabular}

\section{Results}

\subsection{Background of the Time Period}

The extensive use of dyes in wood started in the second half of the 1600s. The use of vitriol and verdigris was limited, and Spanish furniture was characterized by its strength, simplicity and functionality. Bureaus, known as "bargueños", were characteristic of Spanish homes during the 16th century. Their functional role of storage became important to show social status [25]. Inlaid decoration in Spanish furniture, called "taracea", showed a limited use of color; white, brown, black and occasionally, silver and gold were used in simple designs [26]. In comparison, characteristic elements in most of the works using gesägte intarsia are rich colorful designs portraying birds, leaves, flowers, rolled cylinders, ruins, architectonic landscapes through archways and polyhedral compositions inspired by Lorenz Stöer and Wentzel Jamnitzer [20,27]. 
During the rule of King Phillip II, furniture made by Spanish masters followed the national characteristic of functionality and modesty. However, the royal family, of German origin, had a strong preference for Augsburg furniture. Typical Spanish bureaus, or "bargueños," were the favorite pieces of furniture ordered by Augsburg masters. In fact, Bartholomew Weisshaupt, a well-known master in Augsburg, was called "the bureau master", as he was in charge of the making of bureaus for King Charles V and his son, King Phillip II [28]. When King Phillip II built the Royal Monastery of San Lorenzo de El Escorial, Master Weisshaupt was in charge of the making of the famous "German doors" between 1562 and 1568. These doors were made in Augsburg and installed in El Escorial by Master Weisshaup and his son $[20,24]$. Most of the furniture pieces, like the bureaus, were brought to Spain by the King's officials and ambassadors in Germany [25] and also as part of an intense commercial relationship with Augsburg, especially with the Augsburg based Fugger company, that funded Spain during most of the rule of King Phillip II. These pieces of furniture were part of the collection of members of the Habsburg family, which included the King's daughter and his sister, Joanne of Austria, Queen of Portugal, as well as other members of the court [20,28,29].

\subsection{Science behind the Spalting Determination}

Blue-green wood is produced when Chlorociboria species release the secondary metabolite known as xylindein, extracellularly, into wood $[16,30,31]$. Wood stained with xylindein is characterized by differences in pigment saturation across various types of wood cells, due to expansion of pigmented hyphae to sites with higher concentration of sugars $[1,16]$. Where the easily available sugars exist in any given piece of wood are related to how recently the wood was felled (some simple sugars are eaten within days of felling by airborne fungi, such as the bluestains [4]), and what fungi have previously colonized the wood.

Microscopically, wood colored by Chlorociboria sp. often shows a higher concentration of the xylindein pigment in the ray cells than in the vessels, due to how fungi colonize wood $[1,4,16,17,32,33]$. As Chlorociboria fungi first seek out free sugars in wood, then later begin to degrade the wood cell wall [17], colonization, and thereby color, is uneven in wood, as wood sugar placement within wood is uneven $[1,16]$. In contrast, dyed wood typically has color primarily in the vessels and fibers (the path of least resistance), but seldom in the ray parenchyma (smaller, horizontal cells are more difficult to flow into) [10]. Additionally, the color dispersion in dyed wood tends to be much more even across affected cells, due to how the dye is placed into the wood (submersion, vacuum, etc.).

Specifically for the Chlorociboria species of Europe, the fungi are not generally primary wood colonizers. Instead, these fungi tend to be found growing on wood previously decayed by white-rot fungi [34,35], which degrades the lignocellulosic compound [4], transforming wood into a brittle material. For this reason, wood pigmented with xylindein produced by Chlorociboria species, can only be used in small sizes because the wood is highly decayed. As such, blue-green wood could often only be used for small details, such as leaves. Intarsia masterpieces containing larger pieces are very uncommon. In contrast, dyed wood is often found in larger pieces, as the size of the piece is not a limitation for the application of the dye.

Another characteristic that helps determine the presence of spalted wood is the time frame. Spalted wood started to be used at the end of the 13th century, reaching its peak during the 16th century [1]. Dyeing techniques existed, however there were not widely spread. During the 17th century, dying techniques developed to imitate the blue-green wood [1]. Prior to this time period, there was no way to generate a blue-green pigment. Hence, if a piece belongs to the period between the 13th and the 16th, it is almost certain that the remaining blue-green colored wood is natural spalted wood.

\subsection{The Artwork-Spalted}

While marquetry uses inlaid pieces of wood veneers, intarsia uses pieces of sawn wood inlaid in a wood base. Gesägte intarsia is a technique derived from the Italian intarsia. While Italian intarsia 
woodworkers preferred the use of dyed woods, German intarsia guilds, due to the low availability and high prices of dyes, preferred to use the natural palette wood colors. The use of the famous blue-green ("spalted") wood in these works was used primarily to represent vegetation and water.

The specific use of blue-green spalted wood is already known to be in several bureaus commissioned to Augsburg woodworkers, who specialized in gesägte intarsia [20,22] during the reign of Phillip II (1556-1598). Several additional pieces were identified for this study that also fell into this category, but have not yet been confirmed to contain spalted wood. Three bureaus (CE02218, CE02845 and CE02735) were found at the MNAD and one bureau $(82 / 1477)$ was located at the Bilbao Fine Arts Museum. The bureaus were originally from southern Germany, made of "fruit wood"; cherry and plum were used, as well as poplar, walnut, beech and "green colored woods" [20,36].

The first bureau (CE02218), dated 1600, originated from southern Germany, and was found in the MNAD. It was an $18 \times 22 \times 17 \mathrm{~cm}^{3}$ bureau or "bargueño", divided into nine drawers. It had gesägte intarsia work on the sides, top, outside lid panel, inside lid panel and in each one of the drawers front. The piece showed the typical features of Augsburg gesägte intarsia. In this bureau, blue-green spalted wood was mainly used for the representation of abundant leaves (Figure 3a). The leaf color was a dark blue-green, with an irregular distribution of color. The blue-green color saturation was also highly variable. The blue-green pieces in this work met the following categories: Small pieces, color concentrated in rays rather than fibers or vessels, and irregular distribution of color, as it shows variation in the shades of green throughout the piece. These characteristics can be found in spalted wood collected in its natural environment and pigmented by xylindein produced by Chlorociboria sp. Noting the history of this bureau, its origin, and the specifics of the blue-green color, this piece is confirmed as containing spalted wood.

The second bureau (CE 02845) was found in the MNAD, was dated 1600, and originated from southern Germany. It was a $62 \times 104 \times 39 \mathrm{~cm}^{3}$ bureau or "bargueño", divided into twenty-one drawers, each one with intarsia work on the front panel. The design was based on exotic birds. Blue-green wood was used for the representation of the bird's plumage, vegetation and architectural elements (Figure 3b). The blue-green wood pieces in this work met the following categories: small pieces, color concentrated in rays rather than fibers or vessels and irregular distribution of color. The second bureau also shows characteristics consistent with those of spalted wood pigmented by xylindein, found in wood colonized by Chlorociboria sp. This indicates, along with the year of manufacture and the makers, that the blue-green pieces used in the second bureau is also spalted wood.

The third bureau (CE02735), also found in the MNAD, was dated 1600 and originated from southern Germany. It was a $29 \times 34 \times 42 \mathrm{~cm}^{3}$ bureau or "bargueño", made from mahogany with fruitwood and blue-green wood used in the exterior of the drawers with intarsia. This bureau had nine drawers and two doors. The exterior of the drawers as well as the interior side of the doors had intarsia work. The exterior panel of the drawers showed urban views. The interior of the doors showed ruins, archways and geometric figures (See Figure 3c). These themes are consistent with gesagte intarsia motives. Blue-green colored wood was used to portray vegetation and geometric figures. The blue-green pieces in this work met the following categories: small pieces, color concentrated in rays rather than fibers or vessels, and irregular distribution of color, as it shows variation in the shades of green throughout the piece. These characteristics are consistent with wood spalted by Chlorociboria sp. Noting the time period this pieces was made, the woodcrafters who made it, and the coloration pattern, the blue-green pieces in this work are also considered to be also spalted wood.

The fourth bureau (82/1477) was found in the Bilbao Fine Arts Museum. This bureau or "bargueño", is dated 1560-1570 and originated from Augsburg. It was made from Acer sp. (maple), Quercus sp. (oak), Pyrus sp. (pear), Prunus sp. (cherry), Fraxinus sp. (ash), Buxus sp. (boxwood), and Populus sp. (poplar) [20]. It has ten drawers and a central door. The inner face of the front door, all four surfaces of the inner central niche, the interior of the drawer as well as the top and the sides of the bureau were covered with gesägte intarsia (See Figure 3d). The motives consisted of rolled cylinders, geometric figures, birds and vegetation [20]. Blue-green colored wood was used for the 
pieces used to represent vegetation, geometric figures and the plumage of the birds. The blue-green pieces in this work met the following categories: small pieces, color concentrated in rays rather than fibers or vessels, irregular distribution of color, as it shows variation in the shades of green throughout the piece. These characteristics match the characteristics of wood pigmented by xylindein produced by Chlorociboria sp. Combined with the years the piece was made and its makers, this indicates that the blue-green pieces used in the fourth bureau are spalted wood.

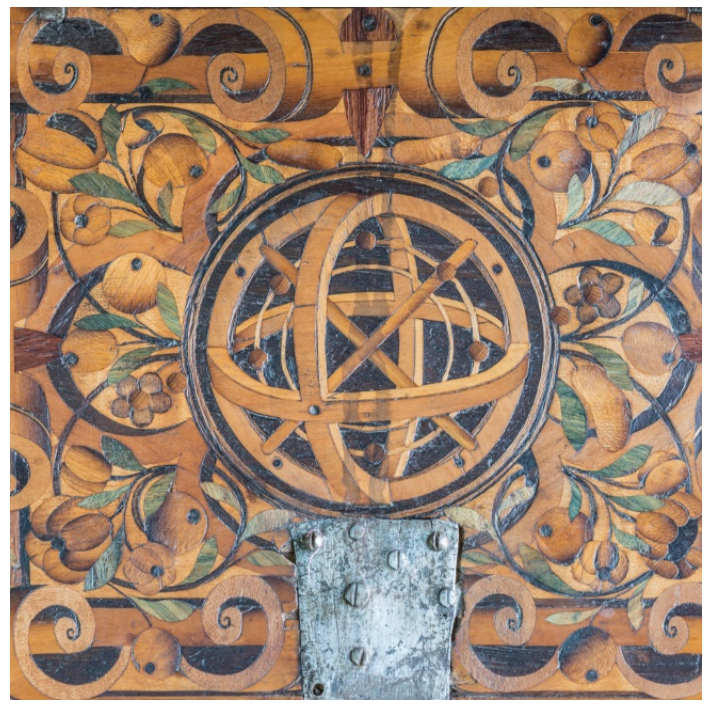

(a)

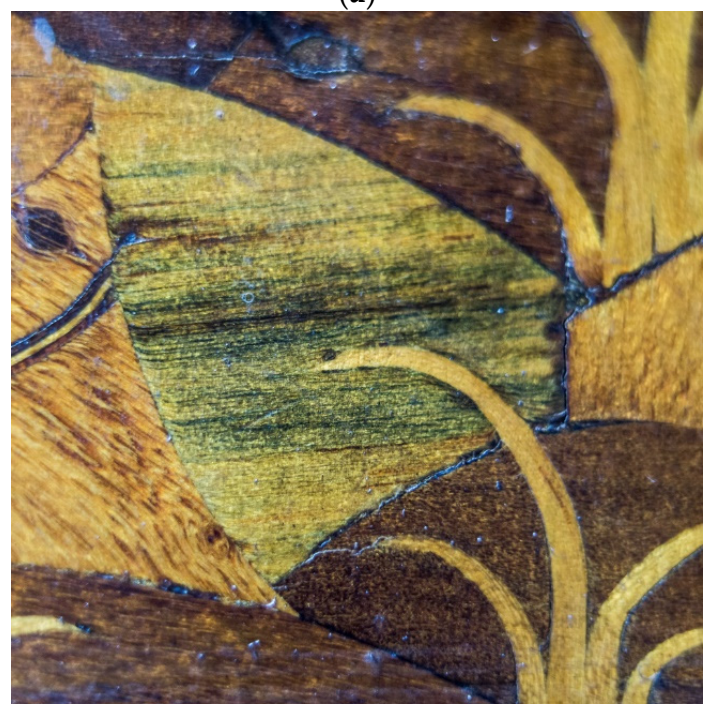

(c)

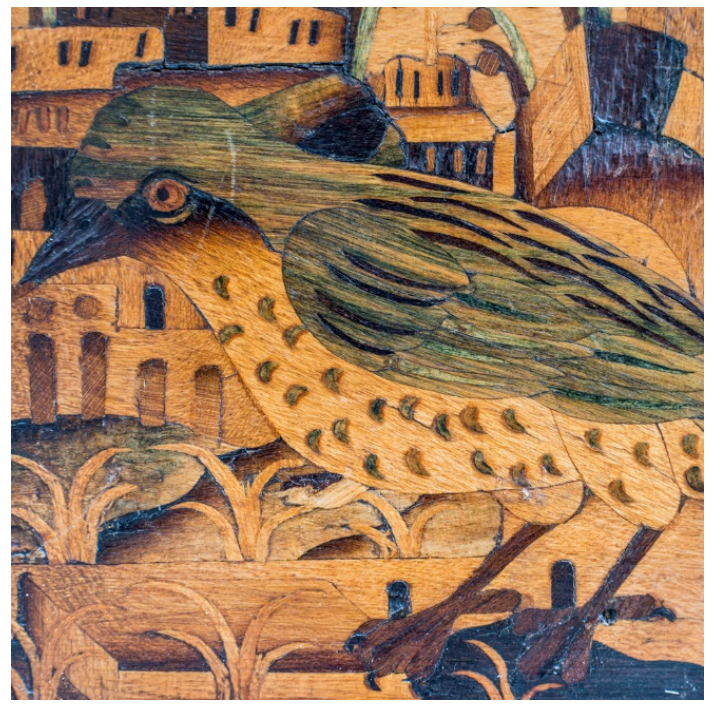

(b)

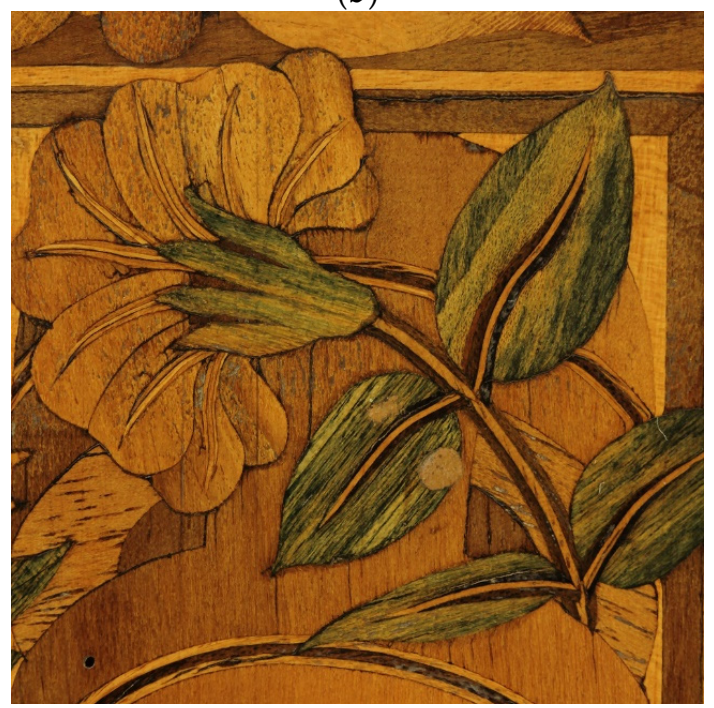

(d)

Figure 3. Images (a) (CE022180, (b) (CE02845) and (c) (CE 02735) show detail of bureaus dated 1600 at the National Museum of Decorative Arts. Image (d) $(82 / 1477)$ shows detail of a bureau dated 1560-1570 at the Bilbao Museum of Fine Arts. The color of blue-green spalted wood in the small sized pieces shows an irregular distribution. In image $c$ the higher concentration of color is noted in the rays. Photos (a-c): Museo Nacional de Artes Decorativas, Spain; Photo (d): Bilbao Museum of Fine Arts, Spain.

\subsection{The Artwork-Not Spalted}

Two of the pieces found during this investigation were likely not made from spalted wood, and are detailed below. 
The first piece was a cabinet (CE05725), from MNAD dated 1776. It was of Spanish or Italian origin. The cabinet presented blue-green colored wood inlaid in marquetry panels. The front was decorated with an inlaid composition of musical instruments, with greca friezes and strings of beads limited by fillets and borders (See Figure $4 a, b$ ). The blue-green pieces of this work showed large pieces of blue colored wood in the front of the marquetry panel. The color was evenly distributed in the fibers and vessels but the rays did not contain any pigment. Noting the date this pieces was made, the size of the pieces used, and the even distribution of the color not within the rays, this piece does not contain spalted wood.

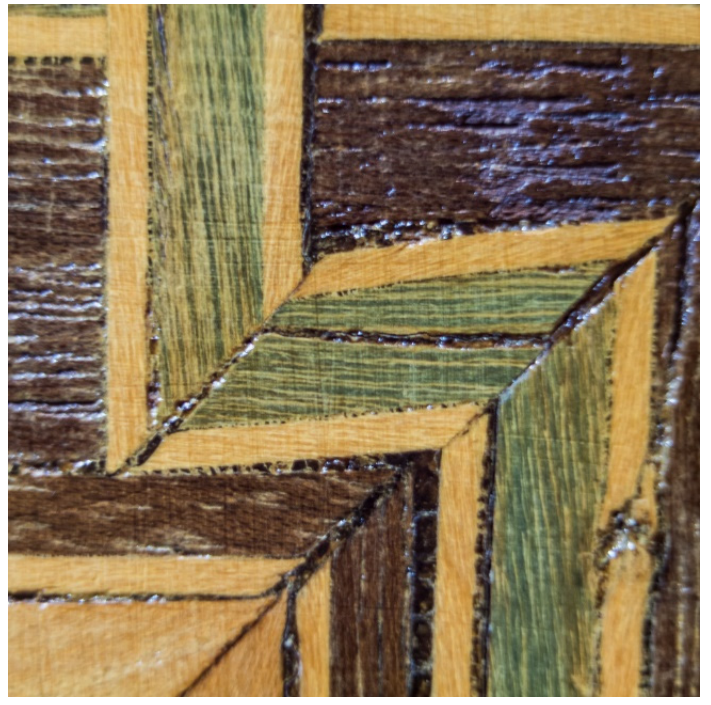

(a)

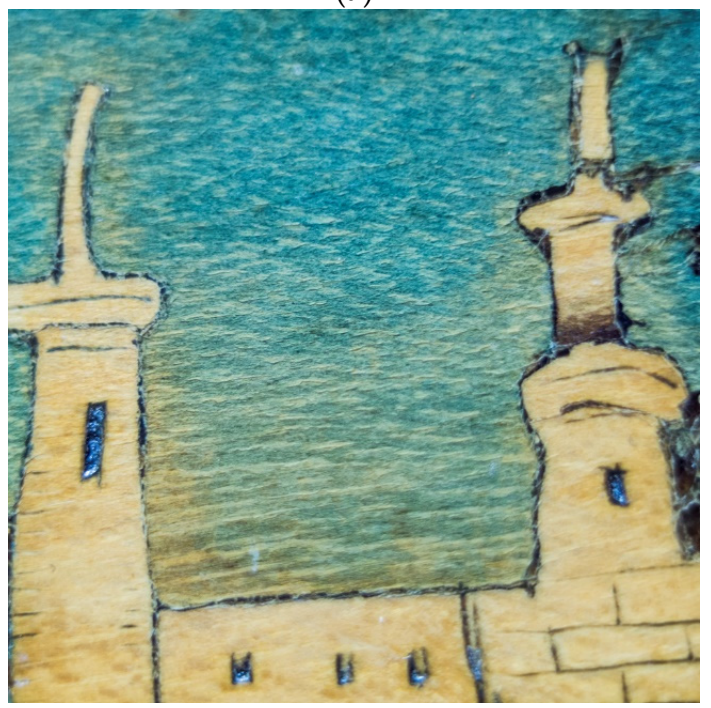

(c)

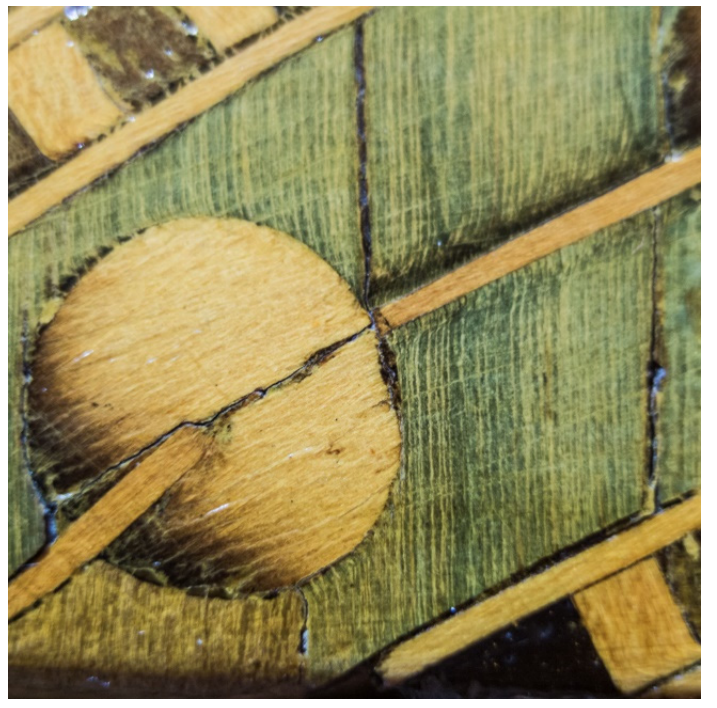

(b)

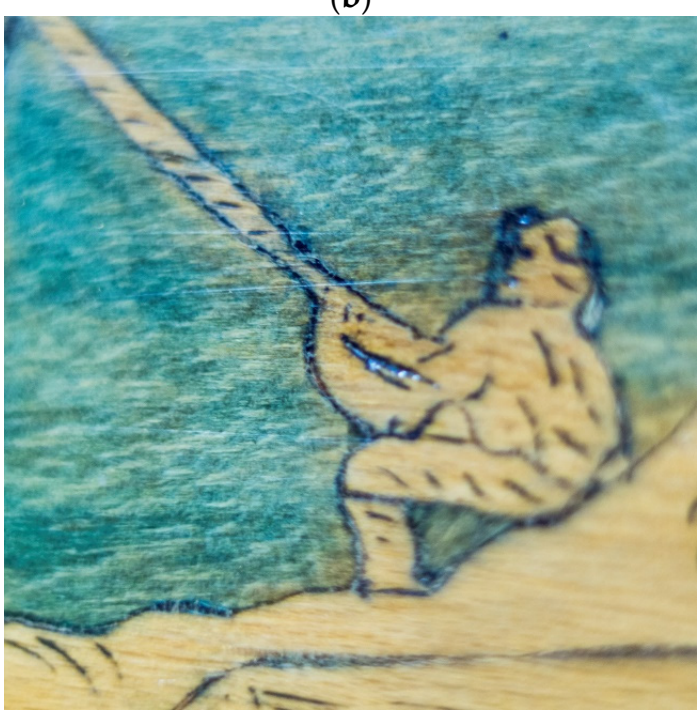

(d)

Figure 4. Images (a) (CE 05725) and (b) (CE 05725) show details of the friezes of the cabinet door, dated 1776 at the National Museum of Decorative Arts. The images show clearly the rays without pigmentation. Images (c) (CE 19340) and (d) (CE 19340) show details of the skirt of a gaming table, dated 1776 at the National Museum of Decorative Arts, made at the Royal Woodworking Workshop. The images show the even distribution of color and the absence of color in the rays. Photos: Museo Nacional de Artes Decorativas. 
The second piece (CE19340) was a gaming table dated 1776, possibly made at the Royal Woodwork Workshop [36]. It was made of mahogany, the skirt had inlaid holly and lemongrass, and the green color areas showed scenes of fishing and hunting. The blue-green pieces of this work were large (the entire skirt had a blue-green panel). The color was evenly distributed and not present in the rays. Due to the year the piece was made and the above characteristics, it likely does not contain spalted wood (Figure 4c,d).

\section{Discussion}

During the 16th century, Chlorociboria wood was used in pieces of German origin brought to Spain due to the strong preference of King Phillip II for gesagte intarsia pieces, especially bureaus that were commissioned in Augsburg. Gesagte intarsia objects were bought by royal families, who used the exquisite techniques and the use of unique materials like Chlorociboria wood as a symbol of social status [25,28]. Chlorociboria wood was considered a commodity in the Augsburg region [20] and had great value [21] as colored woods were rare and expensive [22].

Even though intarsia developed from Spanish-Arab taracea, an inlay technique highly developed in Spain; no artifacts of Spanish origin from the same period showed a technique similar to the German pieces. Both styles were completely different. Spanish furniture is severe, strong and with a limited use of color. There is no evidence that spalted wood was ever used. This is likely due to the secret nature of the woodworking guilds and the protection of the techniques. The intarsiatore guilds in Augsburg and Nuremberg likely held their secrets to gain complete control of the market, as they were the only providers of this type of furniture in Spain (supported by the German origin of the Habsburg family).

All the pieces found in Spanish museums from the 1600s showed the elements that identified them as Augsburg pieces. Chlorociboria wood was used in small pieces to portray leaves, floral patterns, bird's feathers, vegetation and some architectonic elements like roofs and pillars (Figure 5). The visual characteristics indicated that the blue-green material used were pieces naturally pigmented by fungi. The presence of a higher concentration of pigment in the wood rays than in the vessels and the fibers, the irregular distribution, and concentration of color in the wood pieces indicates that the pigment was likely laid by a fungus, specifically one in the genus Chlorociboria.

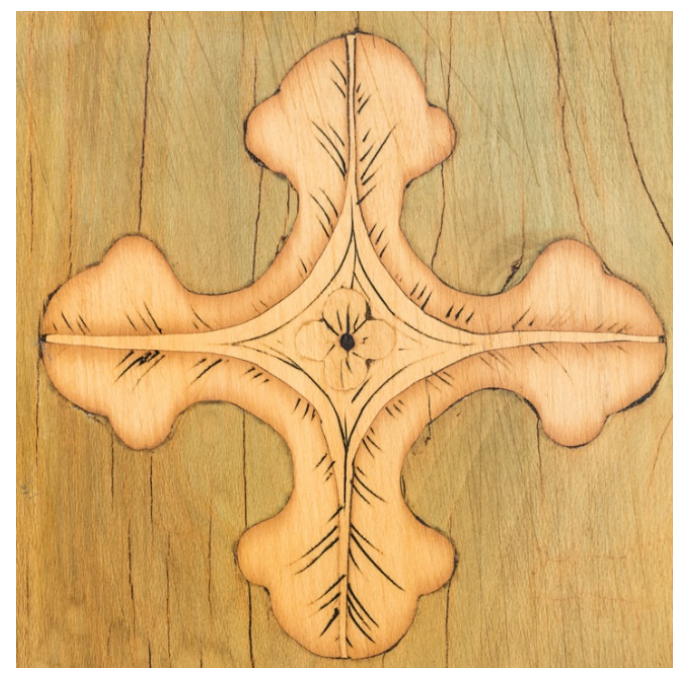

(a)

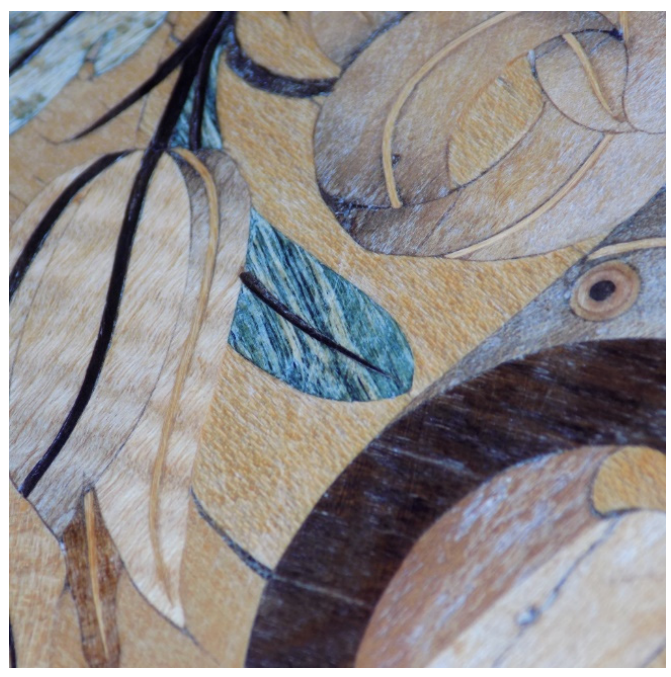

(b)

Figure 5. Image (a) (CE 05638) shows details of the front frame of a cabinet, dated 1801 at the National Museum of Decorative Arts. The color is uniform in a piece of approximately $13 \times 13 \mathrm{~cm}^{2}$, the rays are not pigmented. Image (b) (Royal Monastery El Escorial) shows detail of one of the Ambassadors doors. A spalted wood piece inlaid shows the uneven distribution of color in a piece of approximately $3 \times 3 \mathrm{~cm}^{2}$, the piece shows high concentration of pigment in some areas (Royal Sites Spain). 
The pieces found from later centuries were very clearly colored by different compounds, as the blue-green pigment was much more uniform, and seldom if ever in the ray cells of the wood. This comparison of older spalted wood with blue-green colored pieces from 1800s gives a clear example of the changing mindset of dye work in Spain and Germany during the 1700s-1800s. The discovery of dyes in the 1600s, and the technological advances within alchemy (and burgeoning chemistry) that allowed for more stable blue-green pigments, likely allowed the intarsiatore access to a less expensive, easier to work with, and more available product that could produce a similar visual effect. This change in dye preference likely affected the value and cost of spalted wood, as this material was a valuable commodity during the middle ages [20,21], and the exclusivity of the product for the intarsiatore market drove the material to high cost [1].

\section{Conclusions}

As most museums and collectors have a great deal of stored wood artwork with unknown composition, but are unwilling to have small pieces removed for destructive HPLC analysis, a more reliable, nondestructive test is needed to determine xylindein presence in ancient marquetries. A spalted wood identification checklist was developed as a fast, non-destructive method to identify the presence of blue-green colored wood by Chlorociboria sp., and thereby differentiate the spalted wood from dyed wood, in marquetry artifacts between the 12th and the 20th century. The method was based on the visual assessment of the presence of the color in ray cells, the concentration of the pigment in ray cells, the color distribution in the whole inlaid piece, the size of the piece, and the historical background. Eleven pieces (six furniture pieces and five doors) were found in Spanish museums that contained spalted wood, all from the 1600s, and four were found with dyed wood, all from the 1700s and 1800s. This new, nondestructive method will be useful for museum and personal collections as a fast, reliable assessment of the presence of spalted wood or dyed wood in artifacts that do not allow sampling, and should offer museum curators a new method by which to study, date, and promote their old intarsia and marquetry artwork. With this technique, curators and scientists may be better able to trace the use of spalted wood through the centuries, and shed a light on one of the most guarded secrets in medieval marquetry woodworking.

Acknowledgments: The authors would like to thank the World Wood Day Foundation Grant for its support on this research work. The WWDF covered all costs of the field work. In Spain, the authors would like to extend special thanks to Maria Paz Aguiló-Alonso, for her kind help and outstanding advice on Spanish furniture history and Augsburg pieces. Raquel Carreras Rivery for her kind assistance on the wood identification of the doors at the Royal Site San Lorenzo El Escorial. At the Bilbao Museum of Fine Arts we would like to thank Javier Viar, Director of the Museum, Javier Novo, Head of Collections; Maria Jose Ruiz-Ozaíta, Head of Conservation and Restoration and Iñaqui López Allende, Assistant of the Collections Department. At the Royal Site San Lorenzo El Escorial we would like to thank the National Patrimony Office, to Alvaro Soler del Campo, Chief of the Conservation Department, and to Almudena Pérez de Tudela member of the Conservation Department. At the National Museum of Decorative Arts, we would like to thank the Ministry of Education, Culture and Sports, and to Isabel Maria Rodriguez Marco, from the Documents Department. We also thank Juan Carlos Quindós for the photographs taken at the National Museum of Decorative Arts.

Author Contributions: Patricia T. Vega Gutierrez and Seri C. Robinson conceived and designed the experiments; Patricia T. Vega Gutierrez performed the field work; Patricia T. Vega Gutierrez and Seri C. Robinson analyzed the data. Patricia T. Vega Gutierrez wrote the paper and Seri C. Robinson edited it.

Conflicts of Interest: The authors declare no conflict of interest.

\section{References}

1. Robinson, S.C.; Michaelsen, H.; Robinson, J.C. Spalted Wood, History, Science and Art of an Unique Material; Schiffer Publishing: Atglen, PA, USA, 2016.

2. Robinson, S.C.; Laks, P.E.; Richter, D.L.; Pickens, J. Evaluating loss of machinability in spalted sugar maple. Forest Prod. J. 2007, 57, 33-37.

3. Mallett, K.I.; Hiratsuka, Y. Nature of the "black line" produced between different biological species of the Armillaria mellea complex. Can. J. Bot. 1986, 64, 2588-2590. [CrossRef] 
4. Zabel, R.A.; Morrell, J.J. Wood Microbiology Decay and Its Prevention; Academic Press: San Diego, CA, USA, 1992.

5. Robinson, S.C.; Tudor, D.; Cooper, P.A. Wood preference of spalting fungi in urban hardwood species. Int. Biodeterior. Biodegrad. 2011, 65, 1145-1149. [CrossRef]

6. Robinson, S. Developing fungal pigments for "painting" vascular plants. Appl. Microbiol. Biotechnol. 2012, 93, 1389-1394. [CrossRef] [PubMed]

7. Robinson, S.C.; Tudor, D.; Cooper, P. Utilizing pigment-producing fungi to add commercial value to American beech (Fagus grandifolia). Appl. Microbiol. Biotechnol. 2012, 93, 1041-1048. [CrossRef] [PubMed]

8. Robinson, S.; Tudor, D.; Hipson, S.; Snider, H.; Ng, S.; Korshikov, E.; Cooper, P. Methods of inoculating Acer spp., Populus tremuloides, and Fagus grandifolia logs for commercial spalting applications. J. Wood Sci. 2013, 59, 351-357. [CrossRef]

9. Robinson, S.C.; Tudor, D.; Zhang, W.R.; Ng, S.; Cooper, P.A. Ability of three yellow pigment producing fungi to colour wood under controlled conditions. Int. Wood Prod. J. 2014, 5, 103-107. [CrossRef]

10. Robinson, S.C.; Hinsch, E.; Weber, G.; Leipus, K.; Cerney, D. Wood colorization through pressure treating: the potential of extracted colorants from spalting fungi as a replacement for woodworkers' aniline dyes. Materials 2014, 7, 5427-5437. [CrossRef] [PubMed]

11. Weber, G.; Chen, H.-L.; Hinsch, E.; Freitas, S.; Robinson, S.C. Pigments extracted from the wood-staining fungi Chlorociboria aeruginosa, Scytalidium cuboideum, and S. ganodermophthorum show potential for use as textile dyes. Color. Technol. 2014, 130, 445-452. [CrossRef]

12. Vega Gutiérrez, S.M.; Robinson, S.C. Initial studies on the diversity of spalting fungi in the southern amazon forest of peru. In The Challenge of Complexity; Società Italiana di Microbiologia Agraria-Alimentare e Ambientale: Florence, Italy, 2015; pp. 59-60.

13. Vega Gutiérrez, S.M.; Robinson, S.C. Microscopic analysis of pigments extracted from spalting fungi. J. Fungi 2017, 3, 15. [CrossRef]

14. Vega Gutierrez, S.M. Spalting Fungi: Genetic Identification, Material Interactions and Microscopical Characteristics of Extracted Pigments. Ph.D. Thesis, Oregon State University, Corvallis, OR, USA, 2017.

15. Vega Gutiérrez, S.M.; Vega Gutiérrez, P.T.; Godinez, A.; Pittis, L.; Huber, H.; Stanton, S.; Robinson, S.C. Feasibility of coloring bamboo with the application of natural and extracted fungal pigments. Coatings 2016, 6, 37. [CrossRef]

16. Blanchette, R.A.; Wilmering, A.M.; Baumeister, M. The use of green-stained wood caused by the fungus Chlorociboria in intarsia masterpieces from the 15th century. Holzforsch Int. J. Biol. Chem. Phys. Technol. Wood 1992, 46, 225-232.

17. Richter, D.L.; Glaeser, J.A. Wood decay by Chlorociboria aeruginascens (Nyl.) Kanouse (Helotiales, Leotiaceae) and associated basidiomycete fungi. Int. Biodeterior. Biodegrad. 2015, 105, 239-244. [CrossRef]

18. Michaelsen, H.; Unger, A.; Fischer, C.-H. Blaugrüne Färbung an Intarsienhölzern des 16. und bis 18. Jahrhunderts. Restauro 1992, 98, 17-25. (In German)

19. Otterstedt, A. Investigating green marquetry on bowed-string instruments. The leaves be greene. Galpin Soc. J. 2001, 54, 330-338. [CrossRef]

20. Aguiló-Alonso, M.P. In search of wisdom: An iconographic programme in a 16th-century German bureau with marquetry. In Bulletin Bilbao Fine Arts Museum; Bilbao Fine Arts Museum: Bizkaia, Spain, 2010; No. 5; pp. 15-63.

21. Hellwag, F. Die Geschichte des Deutschen Tischlerhandwerks: Vom 12. Bis Zum 20. Jahrhundert; Verlag-Anst. des Dt. Holzarbeiter-Verbandes: Berlin, Germany, 1924. (In German)

22. Scherer, C. Technik und Geschichte der Intarsia; TOWeigel Nachfolger: Leipzig, Germany, 1891. (In German)

23. Cer.es. Red Digital de Colecciones de Museos de Espana. Available online: http:/ / ceres.mcu.es (accessed on 6 June 2017).

24. Aguiló Alonso, M.P. La Ebanisteria Alemana en el Monasterio del Escorial; Consejo Superior de Investigaciones Científicas (España): Madrid, Spain, 1987. (In Spanish)

25. Piera Miquel, M. Los Muebles con Secreto: Esconder, Exhibir, Aprender. Rev. Hist. Mod. An. Univ. Alicante 2012, 30, 159-175. [CrossRef]

26. Whishaw, B.; Whishaw, E.M. Arabic Spain, Sidelights on Her History and Art; Smith, Elder \& Co.: London, UK, 1912.

27. Aguiló Alonso, M.P. El Mueble en España, Siglos XVI-XVII; Antiqvaria: Minneapolis, MN, USA, 1993. 
28. Perez de Tudela, A. Los Muebles de la Colección de Felipe II y de su Hija la Infanta Isabel Clara Eugenia. In El Culto al Objeto: De la Vida Cotidiana a la Colección; Asociación para el Estudio del Mueble: Barcelona, Spain, 2009; pp. 33-47. (In Spanish)

29. Aguiló Alonso, M.P. Relaciones Entre España e Italia en el Siglo XVII. La Importación de Objetos de lujo; Ayuntamiento: Barcelona, Spain, 2007; pp. 37-47. (In Spanish)

30. Edwards, R.L.; Kale, N. The structure of xylindein. Tetrahedron 1965, 21, 2095-2107. [CrossRef]

31. Liebermann, C. Ueber Xylindein. Ber. Dtsch. Chem. Ges. 1874, 7, 1102-1103. [CrossRef]

32. Tudor, D.; Margaritescu, S.; Sánchez-Ramírez, S.; Robinson, S.C.; Cooper, P.A.; Moncalvo, J.M. Morphological and molecular characterization of the two known North American Chlorociboria species and their anamorphs. Fungal Biol. 2014, 118, 732-742. [CrossRef] [PubMed]

33. Tudor, D.; Robinson, S.C.; Krigstin, T.L.; Cooper, P.A. Microscopic investigation on fungal pigment formation and its morphology in wood substrates. Open Mycol. J. 2014, 8, 174-186. [CrossRef]

34. Blanchette, R.A. Screening wood decayed by white rot fungi for preferential lignin degradation. Appl. Environ. Microbiol. 1984, 48, 647-653. [PubMed]

35. Blanchette, R.A. Degradation of the lignocellulose complex in wood. Can. J. Bot. 1995, 73, 999-1010. [CrossRef]

36. Fichas de Piezas del MNAD; Museo Nacional de Artes Decorativas: Madrid, Spain, 2015. (In Spanish)

(C) 2017 by the authors. Licensee MDPI, Basel, Switzerland. This article is an open access article distributed under the terms and conditions of the Creative Commons Attribution (CC BY) license (http://creativecommons.org/licenses/by/4.0/). 